\title{
SUBMICROSCOPIC STRUCTURE OF HUMAN ARTICULAR CARTILAGE IN THE PERIOD BETWEEN 19 TO 38 WEEKS AFTER FERTILIZATION
}

\author{
D. HORKÝ
}

Department of Anatomy, Histology and Embryology, University of Veterinary Science, 61242 Brno

\author{
Received September 1, 1989
}

\begin{abstract}
Horký D.: Submicroscopic Structure of Human Articular Cartilage in the Period of 19 to 38 Weeks After Fertilization. Acta vet. Brno, 60, 1991: 111-126.

Articular cartilage of 15 and 19 foetuses of both sexes aged between 19 to 38 weeks after fertilization was studied by transmission electron microscopy and scanning electron microscopy, respectively. The specimens, obtained from indicated abortions and spontaneous miscarriages, were processed by routine methods.

In the course of the development of articular cartilage, certain periods can be distinguished which clearly reflect the changes in the submicroscopic structure of its individual components and in the forming of its surface. In the first ninety days, such a period occurs between the 6th and 11 th week after fertilization. Later, such periods occur at the age of 19 to 20 weeks and 27 to 37 weeks after fertilization. The two latter periods were the subject matter of our investigations.

Besides other changes, the period between the 19th and 20th week marks the appearance of intracytoplasmic filaments in the cytoplasm of chondroblasts in the surface and middle layers as an important differentiation sign, and in the 27th week the chondral membrane first appears on the surface of the cartilage. In the period between the 27th and 36th week of development, differentiation changes in chondroblasts continue and, as a result, the cells attain characteristics of chondrocytes of adult cartilage. The fibrous component of intercellular substance becomes more abundant, so that the differentiation between the pericellular and intercellular matrices, particularly in the middle and deep layers, is quite clear.

Up to the 19th to 20th week of development, cartilaginous surface is very uneven. Covered with a surface layer of intercellular matter, numerous chondroblasts extend into the joint cavity. From the 27th week on, and particularly in the 37th week, there is a decrease in the number of chondroblasts, which, before birth, form characteristic cell pairs. The cells are set in depressions separated from the neighbouring area with a groove. Depressions and grooves are the result of a collapsed pericellular matrix, elevations rest on a sublayer of chondroblasts.
\end{abstract}

Ultrastructure, human articular cartilage, prenatal development

Articular cartilage if formed from the mesenchyme during the development of the skeleton as a part of the cartilaginous blastema of the bone primordium, which is made into a definite bone in the course of ossification. From developmental, microscopic and functional points of view, articular cartilage is a part of the joint, which is in fact a specifically differentiated cleft originating from the above-mentioned mesenchymal blastema. The cartilage thus formed is almost perfectly adapted to perform its function in the organism's locomotion. During ossification, the preformed bone primordium is gradually removed. Articular cartilage is not affected by this process and remains intact in the direction of the joint cavity (Bonucci 1967; Scherft 1972; Thyberg $1973 \mathrm{ab;}$ Ali 1976; Anderson and Sajdera 1976; Felix and Fleisch 1976; Hanaoka 1976). 
The process of mesenchymal condensation into blastema takes place in an early stage of embryogenesis. According to Gardner and O'Rahilly (1968), e. g., femoral chondrification already begins in the 6th week after ovulation, and in the 8 th week the primordium of the joint cavity first appears (Sting1 1982). Simultaneously with this process, blood vessels grow into the cartilaginous primordium from the perichondrium (Haines 1933; Hurrel 1934; Levene 1964; Lufti 1970, Stockwell 1971; Agraval et al. 1984). They do not, however, penetrate to the region of the future articular cartilage (Gra y and Gardner 1969; Gardner and Gray 1970) and disappear around the 10th week. Before the joint cavity is formed, a fairly large number of tiny cavities appear in the mesenchyme in the contact area of the future articular surfaces of bones. Its formation is assisted by the first muscles and ligaments in the joint region (D rachman and Sokoloff 1966) and perhaps also the first movements (Glenister 1976). According to Godman et al. (1960), Gould et al. (1974) and Levitt and Dorfman (1974), the cells attain their characteristic positions as a result of the continuing chondrification process. We should, however, add that all the above-mentioned works deal with the question of the development of human articular cartilage only marginally and limit themselves usually to general statements of well-known facts.

That is why we have decided to give as comprehensive survey as possible of the ultrastructure of cells and intercellular matter of human articular cartilage in the prenatal period, including data on the formation of its surface. We mainly focused our attention on those periods which best reflect the submicroscopic changes of individual components of articular cartilage resulting from its continuous differentiation.

\section{Materials and Methods}

To study the ultrastructure of articular cartilage in transmission electron microscopy we took tissue specimens from the hip joint of 15 individuals of both sexes aged 19 to 38 weeks after fertilization. The material was mostly obtained from indicated abortions and only individuals from later stages were obtained from spontaneous miscarriages. Specimens were taken from the convexity of the femure head, while in the case of earlier developmental stages the whole head was used. Specimens were split into blocks of $1 \times 1 \times 2-3 \mathrm{~mm}$ and fixed immediately in $300 \mathrm{mmol} / 1$ or $400 \mathrm{mmol} / 1$ glutaraldehyde solution in phosphate buffer at pH 7.4 for four hours. For a subsequent fixation, $40 \mathrm{mmol} / 1$ solution of $\mathrm{OsO}_{4}$ in phosphate buffer at $\mathrm{pH} 7,4$ for $60 \mathrm{~min}$ was used. Routine methods were used for the dehydration, immersion and embedding in Durcupan ACM. Tissue sections were made on Ultracut Reichert ultramicrotome and stained with lead citrate or uranylacetate and then lead citrate. The sections thus obtained were viewed and photographed under Tesla BS 500 electron microscope. Semithin sections for light microscopy were stained with methylene blue and Azur II.

For scanning electron microscopy of articular cartilage, specimen $5 \times 5 \mathrm{~mm}$ including a part of the subchondral bone were taken from 19 foetuses. Prior to fixation, they were left for $15 \mathrm{~min}$ in a $0.1 \mathrm{mg} / \mathrm{ml}$ hyaluronidase solution at $20^{\circ} \mathrm{C}$, or were washed for $3 \times 15 \mathrm{~min}$ in saline. If hyaluronidase was used, the specimens were washed in a saline for $3 \times 15 \mathrm{~min}$ and then fixed in $10 \%$ formol or glutaraldehyde for 10-14 days. When fixation was concluded, the tissue was drained using the method of drying at a critical point, evaporated with gold using Balzers plating equipment and its surface was studied and photographed using Stereoscan Cambridge scanning electron microscope.

\section{Results}

\section{Ultrastructure of Articular Cartilage in the 19th to 20th Week after Fertilization}

In this stage of development, both the cellular component and intercellular matter of articular cartilage undergo some changes. While the surface-layer chondroblasts still retain the appearance of immature elements, their numbers diminish and thus the intercellular component gets relatively more abundant. Cells of the middle and deep layers exhibit clear-cut structural differences. In the fibrous component of the intercellular matter of all three layers, aperiodic 
and collagenous fibrils can be differentiated which, particularly in the deep layer, predominate over the aperiodic fibrils. In the middle layer, and especially the deep layer, the pericellular and intercellular matrices are already differentiated.

Submicroscopic Structure of the Surface-Layer Chondroblasts Nucleus

Nuclei of surface-layer chondroblasts are spindle-shaped and attain the size of up to $8-10 \times 2-3 \mu \mathrm{m}$.

The nuclear envelope of a usual structure extends against the karyoplasm in shallow invaginations only (Fig. 1, Plate IX) at the end of the volume the perinuclear space is narrow. Ribosomes are thinly bounded to the outer membrane of the nuclear envelope. The appearance of the zonula nucleum limitans is the same as in the surface-layer cells of the previous stage (6-11 weeks) of development.

A cross-section of the nucleus (Fig. 1) shows that chromatin forms a continuous layer at the inner membrane of the nuclear envelope. Sporadic karyosomes are scattered irregularly on the section.

Nucleoli appear seldom and when we detected them at all, they were of the reticular type.

Cytoplasm

Cytoplasm occurs in larger quantities, containing also larger amounts of cellular organelles. Cytoplasmic inclusions are represented by a small amount of glycogen (Fig. 1).

Granular endoplasmic reticulum occurs in the form of short and flat cisternae densely covered with ribosomes (Fig. 1). Cisternae are scattered in the cytoplasm among other organelles. In contrast to the previous stage of development (i. e. 6-11 weeks), we did not come across widely dilated cisternae. Moreover, narrow spaces of granular endoplasmic reticulum are filled up with medium-dark material in this stage of development (Fig. 1).

Agranular endoplasmic reticulum consisted of smooth small vesicles and larger vacuoles, usually near the surface of the cell (Fig. 1). When they appear near Golgi complex, they are probably derivates of its structures.

Golgi complex in cytoplasm of chondroblasts of the surface layer takes up a relatively large area in sectioned material (Fig. 1) and is composed of several Golgi fields. The diktyosome is relatively small, a conspicuous feature is a large number of vesicles of Golgi complex.

Mitochondria are of a usual structure and size. Mitochondria with a clear matrix are a more frequent finding.

Ribosomes are either attached to the outer membrane of the nuclear envelope and the cisternae of granular endoplasmic reticulum or scattered freely in the cytoplasm.

In this stage of development; lysosomes form a regular part of cytoplasm of the surface-layer chondroblasts (Fig 1). They are irregularly oval in shape, reach 0.2 to $0.5 \mu \mathrm{m}$ in size and contain homogenous material of middle to high density (Fig.1).

Cell membrane. Cytoplasm of surface-layer chondroblasts very often projects outwards to form massive processes, covered with cell membrane (Fig. 1). Processes of individual cells touch each other and structures similar to desmosomes (Fig. 1) are occasionally formed at the points of contact. Besides processes 
of this type, cytoplasm also extends into much smaller processes of $0.5-1 \mu \mathrm{m}$ in size, which can be found near cells both in longitudinal and cross-sections (Fig. 1). Cell membrane forms infrequent pinocytotic vesicles.

In cytoplasm of chondroblasts of this layer, glycogen occurs in small quantities only. Its grains are usually agglutinated in small clusters, situated in various places in the cytoplasm among other structures (Fig. 1). On rare occasions, glycogen was found in larger quantities, occupying a large part of cytoplasm.

As in the previous stage, cytoplasmic fibrous structures were observed only rarely. When intracytoplasmic filaments did occur, it was usually in the form of a fine bundle of small filaments in the vicinity of cell membrane (Fig. 1).

\section{Submicroscopic Structure of Middle-Layer Chondroblasts}

Chondroblasts of the middle layer of articular cartilage in the period between the 19th and 20th week after fertilization are cells of irregularly oval shape, reaching a size of $10-12 \times 5-7 \mu \mathrm{m}$ (Fig. 2). They do not differ significantly in the shape, size or content of organelles from chondroblasts of the middle layer of the preceding period, with the exception of the chromatinl arrangement and the amount granular endoplasmic reticulum.

\section{Nucleus}

The nucleus is of an oval shape, attaining the size of $8 \times 4 \mu \mathrm{m}$. Nuclear envelope has its usual structure. Its outer membrane is densely covered with attached ribosomes, and the outer membrane passes from place to place into structures of granular endoplasmic reticulum (Fig. 2, Plate X). In some parts, the perinuclear space widens up to three times its original width. Nuclear pores are relatively frequent.

Chromatin forms a continuous rim near the inner membrane of nuclear envelope. Between the rim and the envelope there is zonula nucleum limitans in the form of a thin layer of granular substance of medium electron density. Moreover, chromatin forms infrequent karyosomes, which are seen scattered all over the nucleus in sectioned material.

Nucleoli are rarely found. When one is found, it is a single nucleolus of the reticular type.

\section{Cytoplasm}

In this stage of development, cytoplasm of chondroblasts of the middle layer of articular cartilage exhibits no significant differences from the cytoplasm of surface layer chondroblasts as regards its amount and the content of cellular organelles, with the exception of the amount of granular endoplasmic reticulum.

Granular endoplasmic reticulum occurs in the form of sporadic flattened cisternae, usually positioned among other organelles at the periphery of cells (Fig. 2). It is clear that its structures originate also from the outer membrane of the envelope (Fig. 2), from where they radiate as evaginations of various présnoot shapes to cytoplasm where they, e.g. widen in a club-like fashion and split off in the form of vesicles (Fig. 2) As in the preceding stage, internal spaces of cisternae are filled up with granular, medium-dense material.

Agranular endoplasmic reticulum is represented by vesicles positioned mainly near the structures of Golgi complex. 
Golgi complex is formed by small diktyosomes and a fairly large number of both small and large Golgi vesicles. In some cases it extends over several fields at the periphery of cytoplasm.

Mitochondria do not differ in size from these organelles in other layers but they usually have thinly distributed cristae with strikingly clear matrix (Fig. 2)

Lysos omes occur in cytoplasm of middle-layer chondroblasts only sporadically. They have the appearance of dark corpuscles of $0.1 \mu \mathrm{m}$ in size (Fig. 2).

Cell membrane. Cytoplasm of middle-layer chondroblasts extends into infrequent, short processes covered with cell membrane of usual architecture. The processes seldom reach the length of $1 \mu \mathrm{m}$ and reach the surrounding intercellular substance. Pinocytotic vesicles are more frequent than in middle-layer chondroblasts of the previous stage. Fine collagenous fibrils are set in a close vicinity of the cell membrane.

Glycogen forms a regular part of cytoplasm. Its granules are most frequently agglutinated in a single large district at the pole of the cell and several smaller clusters scattered in various places in cytoplasm (Fig. 2).

Cytoplasmic fibrous structures occur in the form of short bundles of filaments positioned either perinuclearly or at the periphery of the cell (Fig. 2).

\section{Submicroscopic Structure of Deep-Layer Chondroblasts}

In this stage of development, deep-layer chondroblasts of articular cartilage are cells of an irregularly oval or even rounded triangular profile, attaining size of about $10 \times 6 \mu \mathrm{m}$ (Fig. 3 Plate XI). They mainly occur set separately in intercellular substance.

\section{Nucleus}

The shape of the nucleus copies that of the cell, attaining size of $8 \times 4 \mu \mathrm{m}$.

Nuclear envelope is formed by two membranes which merge in places of nuclear pores. Compared to nuclei of the middle layer, they produce deeper invaginations (Fig. 3). Ribosomes are attached in large numbers to the outer membrane but links with the cisternae of granular endoplasmic reticulum are rare.

Zonula nucleum limitans is well-defined (Fig. 3) and adjoins the internal membrane of nuclear envelope.

Chromatin creates a continuous layer near the internal membrane of nuclear envelope, which is interrupted only in places of nuclear pores. In sectioned nuclear material, moreover, individual karyosomes occur in a larger number than in middle-layer nuclei.

Nucleoli are not prominent and when found at all, they are of reticular type.

Cytoplasm

Granular endoplasmic reticulum has the shape of flattened cisternae or dilated vesicles of various length, situated mainly at the periphery of cells (Fig. 3). Both cisternae and vesicles are filled up with medium-osmiophilic granular material.

Agranular endoplasmic reticulum is present in larger quantities than in the previous stage. Sectioned material clearly shows that its structures in cytoplasm can be formed from envaginations of the cell membrane, which is particularly true about vesicle in its vicinity.

Golgi complex is represented by a large number of small vesicles (Fig. 3) 
which are usually agglutinated in a single district. Among the small vesicles, sporadic large Golgi vacuoles may occur. We found no transport vacuoles.

Mitochondria are neither numerous nor prominent organelles of cytoplasm of deep-layer chondroblasts.

Ribosomes are partly attached to the outer membrane of nuclear envelope and to cisternae of granular endoplasmic reticulum and partly are diffusely distributed in cytoplasm.

Lys os omes represent a regular part of cytoplasm of chondroblasts in the deep layer (Fig. 3) even though they occur in small numbers only. They appear as dark corpuscles 0.3 to $0.5 \mu \mathrm{m}$ in size and are as a rule located at the cell periphery.

Cell membrane. Cytoplasm of deep-layer chondroblasts forms numerous short processes practically over all of surface of the cell. The processes are covered with cell membrane, their length and width not exceeding 1 and $0.3 \mathrm{\mu m}$ respectively. Some of the processes are bifurcated and bent, so that we can find them both in tangential sections as well as cross-sections in the vicinity of cells. The processes penetrate into the pericellular matrix.

\section{Arrangement of Intercellular Substance of Articular Cartilage}

The surface of articular cartilage in the 19th and 20th week of development presents a regionally differentiated appearances. In some parts, either chondroblasts or their cytoplasmic processes (Fig. 1) covered with only a thin layer of intercellular substance penetrate to the immediate vicinity of the surface. Intercellular substance of the surface layer is partly composed of collagenous fibrils, whose quantity has increased compared to the previous stage, and partly of aperiodic fibrils and amorphous ground substance, whose relative amount in the surface layer is decreasing. Intercellular substance is not clearly differentiated into the pericellular and intercellular matrices. Collagenous and aperiodic fibrils often penetrate to the immediate vicinity of cell membrane of chondroblasts (Fig. 1).

In the middle layer (Fig. 2) there are aperiodic fibrils and collagenous fibrils set in abundant amorphous substance. Both types of fibrils occur in immediate vicinity of cell membrane, rendering their differentiation into pericellular and intercellular matrices impossible.

The greatest changes in the composition of intercellular substance occur in the deep layer (Fig. 3, 4, Plate XII). Compared to the previous stage of development, collagenous fibrils are completely predominant, often arranged in bundles oriented roughly parallel to the surface of cells. In the vicinity of chondroblasts, specialized districts begin to form, i. e. pericellular matrix filled up with mainly predominant amorphous substance and aperiodic fibrils (Fig. 3). In the intercellular matrix, bundles of collagenous fibrils are crowded at a longer distance from cells, among which we can find districts composed of meshwork of fine filaments (Fig. 4). As can be seen in sectioned material, they create typical collagenous fibrils. It is clear that clusters of filaments represent tropocollagenous fibrils, which are changed into collagenous fibrils in intercellular substance.

\section{Ultrastructure of Articular Cartilage Between 27 th and 37 th Week After Fertilization}

This period marks the differentiation of both cells and intercellular substance of articular cartilage. Cells in both the surface, middle and deep layers attain gra- 
dually submicroscopic signs of chondrocytes and are deposited in individual layers in a typical manner. In intercellular substance, collagenous fibrils begin to predominate over aneriodic fibres, which only form an important component in a small layer bordering with the joint cavity, and in the areas of the pericellular matrix.

\section{Submicroscopic Structure of Surface-Layer Chondroblasts}

Surface chondroblasts are oval or even spindle-like elongated cells of $10-11 \times$ $\times 5-6 \mu \mathrm{m}$ in size (Fig. 5, Plate XIII). In intercellular substance, they are set separately, oriented parallel to the cartilaginous surface.

\section{Nucleus}

The shape of the nucleus of surface chondroblasts copies the contours of the cell. The nucleus is relatively large, attaining the size of $8 \times 3-4 \mu \mathrm{m}$.

Nuclear envelope has a usual structure. Its outer membrane densely packed with attached ribosomes exhibits envaginations in places and becomes a part of granular endoplasmic reticulum (Fig. 5). The perinuclear space is narrow, nuclear pores are infrequent.

Chromatin creates karyosomes of various sizes, laying next to the internal membrane of the nuclear envelope (Figs. 5, 6, Plate XII). Larger agglutinations of chromatin can be found only near the nucleolus (Fig. 5), which makes the differentiation of perinucleolar chromatin difficult.

$\mathrm{Nucleoli}$ are a very frequent finding. They are about $1.5 \mu \mathrm{m}$ in size and always contain a nucleolonema (Fig. 5).

Cytoplasm

Cytoplas $m$ is accumulated in larger quantities at both poles of the cell, while in other areas it forms only a narrow rim around the nucleus (Figs 5, 6).

Granular endoplasmic reticulum is represented by short flattened cisternae and also by sporadic broad sacks on the other (Figs. 5, 6). Some of the cisternae are branching and interconnecting. Both the flat cisternae and sacks are filled with granular medium-osmiophilic material (Figs. 5, 6).

Agranular endoplasmic reticulum was discovered only very rarely. If found at all, it was in the form of smooth vacuoles.

Golgi complex takes up only a small district in the cytoplasm of chondroblasts (Fig. 5). It only consists of three smooth and short cisternae with a small number of small vesicles placed in its vicinity.

Mitochondria are relatively numerous. They have their usual architecture and besides rounded mitochondria, also rod-like mitochondria occur from time to time (Fig. 5).

Lys os omes occur only very rarely in cytoplasm of chondroblasts of this layer. They form corpuscles about $0.1 \mu \mathrm{m}$ in size and contain granular material of various density (Fig. 5).

Cell membrane. Cytoplasm on most of the cellular surface exhibits no major irregularities, the exception being polar regions of cells where it extends into several short and frequently bifurcating processes (Fig. 6, Plate XII). The processes are about $0.5-0.8 \mu \mathrm{m}$ long and reach into the neighbouring intercellular substance.

No fatty droplets or glycogen were found in the cytoplasm of surface-layer chondroblasts. 
Cytoplasmic fibrous structures are present in the form of fine bundles of filament $1-2 \mu \mathrm{m}$ in length, extending along the cell periphery (Fig. 6).

\section{Submicroscopic Structure of Middle-Layer Chondroblasts}

Middle-layer chondroblasts are cells of the same size as those in the surface layer. In intercellular substance they usually occur in pairs (Fig. 7, Plate XIV) and have an oval or even slightly spindle-like shape.

Nucleus

The appearance and arrangement of nuclei of middle-layer chondroblasts do not differ from the nuclei of surface chondroblasts (Fig. 7).

Nucleolus is a sporadic finding and if found at all, it was always of the reticular type.

Cytoplasm

Cytoplasm occurs at the same amount as in the surface layer, and also its distribution in relation to the shape of cells is similar.

Granular endoplasmic reticulum forms numerous narrow cisternae distributed mainly in cytoplasm at either pole of the cell (Fig. 7) and its profiles also surround the nucleus. Its membranes have ribosomes attached to them and the inside is filled with material of medium electron density (Fig. 7).

Agranular endoplasmic reticulum is present in the form of sporadic smooth vacuoles, scattered randomly among organelles.

Golgi complex is not prominent at all, taking up only a small district in cytoplasm. Besides a small diktyosome, its most conspicuous part are numerous small Golgi vesicles (Fig. 7).

Compared to the surface layer, mitochondria are much more numerous (Fig. 7). Besides rounded or even oval mitochondria, we can also find their elongated or even rod-like versions.

Although they occur in small numbers, lys osomes form a regular component of cytoplasm of chondroblasts in this layer. They are oval or even rounded corpuscles $0.2-0.4 \mu \mathrm{m}$ in size, containing both homogeneous electron-dense material and medium-osmiophilic granular substance (Fig. 7).

Cell membrane. All over the surface, cytoplasm extends into short and wide processes that also contain organelles and form sporadic thin processes of up to $2 \mu \mathrm{m}$ long that reach into intercellular substance. Some of these processes are bent and in this case, their cross-sections also be demonstrated (Fig. 7). Pinocytotic vesicles are not very numerous.

We observed no fatty droplets, glycogen or cytoplasmic fibrous structures in cytoplasm of middle-layer chondroblasts.

\section{Submicroscopic Structure of Deep-Layer Chondroblasts}

Chondroblasts of the deep layer of articular cartilage are cells of rather smaller in size $(8 \times 3-4 \mu \mathrm{m}$, Fig. 8, Plate XIV) than those in the middle layer. They are either oval or irregularly triangular in shape and are usually arranged in stacks of 3 or 4 cells towards the surface of the cartilage.

\section{Nucleus}

In their architecture or appearance, nuclei of deep-layer chondroblasts do not differ from those in the middle or surface layers. 
Nucleolus is found only rarely. When observed at all, nucleoli were about $1 \mathrm{~m} \mu$ in size and always contained nucleolonema.

\section{Cytoplasm}

Compared to middle-layer chondroblasts, cytoplasm occurs in smaller amounts and its density is strikingly high.

Granular endoplasmic reticulum occurs in large amounts. Its narrow cisternae are either densely crowded together or broadly dilated at cell peripheries (Fig. 8). Dilated cisternae contain fibrous material, while narrow reticular spaces are filled up with granular substance of medium density.

Agranular endoplasmic reticulum occurs very rarely in the form of sporadic vacuoles.

Golgi complex is not expressed prominently: it takes up a small district only and is only rarely demonstrated in sectioned material.

Compared to the previous period, the number of mitochondria is small. Their architecture or size shows no differences from mitochondria of chondroblasts of the surface and middle layers (Fig. 8).

Although not very numerous, lysosomes occur regularly. In size and appearance they exhibit no differences from lysosomes of the middle layer.

Cell membrane. On the most of the surface, cytoplasm is smooth with only infrequent processes of $0.8 \mu \mathrm{m}$ long, reaching into the surrounding intercellular substance (Fig. 8). Depending on the arrangement of this intercellular substance, the processes penetrate either into the pericellular or the intercellular matrix, and in some cases the cell membrane immediately adjoins collagenous fibrils (Fig. 8).

There are no cellular inclusions in cytoplasm of deep-layer chondroblasts.

\section{Arrangement of Intercellular Substance of Articular Cartilage}

In the period studied, the fibrous component of the intercellular substance of articular cartilage with a predominance of thin collagenous fibrils in the surface and middle layers became more abundant (Figs. 5, 7), while the deep layer (Fig 8) contains typical collagenous fibrils arranged in bundles just as in the previous period.

The surface of articular cartilage is formed in two ways. In separate locations, parts of up to $8 \mu \mathrm{m}$ long are formed, consisting of bundles of fine filaments (Fig. 4) which come into an immediate vicinity with the joint cavity. Towards the inside of the joint cavity, these bundles are overlaid with a thin layer of amorphous substance with sporadic filaments, separated clearly from the bundles. Deeper below the surface layer, intercellular substance is composed of collagenous fibrils, radiating in various directions (Fig. 5). In this period, pericellular matrix in the vicinity of chondroblasts is already clearly formed, where collagenous fibrils penetrate in limited numbers only (Fig. 5).

In the second case (Fig. 6), only very short parts consisting of fine bundles of filaments are formed, with areas formed by intercellular substance between them. Filament bundles, similar to those described in the previous case, are found under this type of surface at the depth of about 1.2-1.5 $\mu \mathrm{m}$, and other similar structures were observed under the uppermost chondroblasts (Fig. 6). In areas with this type of architecture, pericellular matrix is not clearly formed and collagenous fibrils are in a close contact with cell membrane (Fig. 6). 
In the middle layer, intercellular substance is clearly differentiated into intercellular and pericellular matrices, particularly in separately-occurring cells (Fig. 7).

\section{Scanning Electron Microscopic Appearance of Articular Cartilage}

Around the 20th week of development, the appearance of articular cartilage undergoes considerable changes. Elevations are semi-spherical or spindle-shaped, their distribution, however, is different (Fig. 9, Plate XV). In the 20th week they undergo a kind of an aggregation. They form characteristic groups of 3-4 structures lined one after another, which are of a similar shape as in the previous period. Among these groups or lines of elevations, there are relatively extensive districts whose surface is marked with mound-like structures. Between the ridges of mounds there are shallow grooves extending in some cases into about a third of the elevations.

The next period when the surface configuration of articular cartilage undergoes further changes is the time from the 36th week of development to parturition. As shown in an overall magnified view (Fig. 10, Plate XV), the surface of articular cartilage is much less rough than in the previous period. Low prominences in the form of rounded or slightly oval structures can only be observed, either solitary or in pairs. Between them, there are either shallow depressions or low ridge-like lines. At medium and large magnification (Figs. 11 and 12 respectively, Plate XVI), the detailed arrangement of the surface can be observed. It becomes clear that koth solitary and $j$ aired prominences are bordered with a groove which separates them from the surrounding only slightly corrugated surface. Some of the paired prominences form typical figures of eight (Figs 11, 12) set in a their common depression, or two neighbouring elevations are set so close to each other that the boundary between them becomes indistinct (Fig. 12). On the basis of correlations of transmission electron microscopic observations of the structure of articular cartilage we have come to the conclusion that these prominence represent chondroblasts laying on the surface, while the bordering groove or furrow is the results of a collapse of a district of pericellular matrix.

\section{Discussion}

Light microscopic studies of early ontogenetic development of articular structures in man have been made by a large number of authors (Gray et al., 1957; Gardner and O'Rahilly 1968; Čihák 1972; O'Rahilly and Gardner 1975; Glenister 1976; Levitt and Dorfman 1974, inter alia). It follows from these works that articular surfaces as well as other joint components come into existence in the period between the 6th and 10th week after fertilization and that the joint cavity appears in the 8th week (Gardner and O'Rahilly 1968). Very little information, however, is available on th ? prenatal development of the submicroscopic structure of human artic slar cartilage.

In our group of human embryos, we found an open cavity of the hip joint from the 6th week after fertilization. This observation is in fairly good agreement with the data published by Gardner and O'Rahilly (1968), who focused their attention on the knee joint. If we take into account the differences in the proximodistal sequence, then our observation does not contradict these data. Moreover, certain inaccuracies in the determination of the length of pregnancy and the crown-rump length should be taken into consideration. 
In the study of articular cartilage in not only man but also lower mammals (Horký 1983 ; 1986; 1987) we found that certain periods in the dynamics of the prenatal development can be distinguished in which distinct changes in the ultrastructure of cells and the qualitative and quantitative arrangement of intercellular substance and its arrangement take place.

In the 6th week, the primordium of the femoral head is completely composed of cartilage and the joint cavity has already been formed, which was also confirmed by O'Rahilly and Gardner (1975). In this stage, the cartilaginous primordium has all the characteristics of an immature cartilaginous tissue. Cells are uniform in their appearance both on the surface and in a deeper zone, they are set in an abundant intercellular substance with a predominance of its amorphous component. Intercellular substance produced by chondroblasts (Sheldon and Kimbal 1962) is arranged in a different way on the surface of articular cartilage, where it is formed by sor ewhat denser layer com osed of aperiodic fibrils.

Important changes in the ultrastructure of human articular cartilage take place in the period between the 8th and 11th week of the intrauterine development. While the appearance of cells in the surface layer does not change in any significant way, some cells deeper under the surface attain characteristics of more differentiated elements. With a certain approximation, these changes can be used as a basis for distinguishing three layers in articular cartilage of an adult man and experimental mammals (Palfrey and Davis 1966; Weiss et al. 1968; Vignon et al. 1976; Horký $1980 ; 1983 ; 1986 ; 1987)$. In the surface and middle layers, cells are oriented parallel to the surface of the cartilage (Godman et al. 1960; Gould et al. 1974; Levitt and Dorfman 1974). According to these authors, this is because they are transferred from the region of the chondrification center, while Clark (1971 a; b; 1974) and Zimny and Redler (1972) believe that it is the optimum situation from the mechanical point of view.

As regards the occurrence of blood vessels, they have not been described in any human material and we did not find any in our material, either. This contrasts with the situation in articular cartilage of lower mammals (Horký 1986). We did not when find the cannals described by Hurrel (1934), Levene (1964), Lufti (1970), Stockwell (1971) in the deep layers of the primordium of the femoral head, which is penetrated by the vessels from the perichondrium. In contrast to papers by Stockwell (1967) and Ghadially (1983), we were unable to confirm an increased number of mitoses in the middle layer.

An important symptom of differentiation of intercellular substance and thus also an indicator of the ability of articular cartilage to perform its function in the joint is the formation of its surface. We observed the first signs of densification of the fibrous component of intercellular substance in the 19th week of development in the deep layer of articular cartilage. Aperiodic fibrils begin to agglutinate into bundles and it can be seen quite clearly that they are beginning to form collagenous fibrils. Until the 27th week, the surface of articular cartilage was considerably rough and aperiodic fibrils of the surface layer even project into the joint cavity. In this period, the segments covered with bundles of fibrillar material of various length and thickness begin to form. They are considered the primordium of chondral membrane (Wolf 1946; 1969; 1975; McConnail 1951; Weiss et al. 1968; Meachim and Stockwell 1973; 1979; Stockwell and Meachim 1979; Horký 1980; 1983; 1986). McCutchen (1966) and Maroudas (1973) believe that this structure is formed by ultrafiltration of joint fluid through the surface layer of cartilage. We, on the other hand, assume that chondral membrane 
is formed by tropocollagenous bundles of filaments along the surface of articular cartilage, without their polymerization into typical collagenous fibrils. As regards centrioles and cilia, we can confirm observations of Scherft and Daems (1967), Stockwell and Meachim (1973; 1979), Horký (1978; 1980), Ghadially (1982; 1983), Vidinov and Vasilev (1985) concerning articular cartilage of both man and lower mammals: all of these authors mention a higher incidence of centrioles and cilia in young individuals. The smaller amount of glycogen, among other things testifies to the activity of the chondroblasts of human articular cartilage in the 19th and 20th weeks.

From the 20th week on, small numbers of vimentine intracytoplasmic filaments begin to appear in the cytoplasm of chondroblasts in the surface and middle layers of articular cartilage. These structures grow rapidly in number from the 27th week of development. Their number gradually increases with age and in adult individuals they may even take up a considerable part of the cytoplasm (Weiss and Mirrow 1972). According to their agglutination in the cytoplasm, some authors assessed the overall metabolic state of cells (Thyberg et al. $1973 \mathrm{ab}$; Wiltberger and Lust 1975), or the process of cell ageing (Curtiss and Klein 1965; Ghadially et al. 1970; Dearden et al. 1974; Meachim and Fergie 1975), and their quantities during pathological states were studied (see surveys by Horký 1980, Ghadially 1982), because it used to be assumed that it was a tropocollagen (Revel and Hay 1963; Goldberg and Green 1964). In their works, Lazarides (1980), Porter and Tucker (1981) proved that these filaments were made up of various proteins and that the filaments in cartilaginous cells were of the so-called vimentine type. They form a tri-dimensional meshwork, which is present in the cytoplasm microtubules (Roberts and Hyams 1979) in determinig the shape of the cell. It is still not clear, however, whether they get attached to the cellular membrane.

In intercellular substance of the surface layer, relatively massive and long bundles of fine filaments are located either at the surface or deeper in this layer. It cannot be excluded that the deeper-set bundles are pushed towards the surface of articular cartilage, while the intercellular substance which is on top of them is peeled off to the joint cavity. This idea is, in fact, supported by some of our observations. In the period studied, the fibrous component of the middle and deep layers in man becomes more abundant. At the same time, differentiation into pericellular and intercellular matrices is quite distinct in this period and as regards isogenetic groups, partitions in the common lacuna are formed.

In the prenatal period, the surface of articular cartilage exhibits considerable changes in its formation. Even when we take into account objections of some authors to the methods of scanning electron microscopy for the study of articular surfaces (Bloebaum and Wilson 1980; Ghadially 1983), we cannot dismiss lightly the large number of new information provided by this study of surfaces. On the basis of as yet published works (Ghadially et al. 1978; Longmore and Gardner 1978; Moschurchak and Ghadially 1978; Puschmann 1978) on experimental animals as well as man (see e.g. comprehensive survey by Ghadially 1983 ) it is clear that the number of irregularities caused by chondroblasts deposited on the surface grows smaller in the course of development and the cartilage surface gets smoother, e.g., in the 36th week of intrauterine development in man small round elevations are discernible on the surface, set in shallow, pits. Our observation is in agreement with the findings published by particularly Moschurchak and Ghadially (1978) and Longmore and Gardner $(1975 ; 1978)$, who compared their results with findings obtained with interference microscope. It 
is clear (Horký 1984) that fixation and dehydration artifacts are produced easily particularly in embryonal material because articular cartilage in an early stage of its development contains a considerable amount of water, while proteoglycans and the fibrous component still remain largely unformed (Freeman and Meachim 1973). In the course of development, however, we can observe what could be described as sinking of formerly considerably prominent chondroblasts, separated by a furrow from the surrounding matrix. The furrow is due to a collapse of the newly appearing pericellular matrix, which is at first mainly composed of amorphous matter with a high water content, so that dehydration may cause a collapse of an entire district (Clarke $1971 \mathrm{a} ; \mathrm{b} ; 1974)$. With an increasing amount of the fibrous component in the intercellular substance, the sagging becomes less and less apparent. This is another fact which can to a certain extend provide information on the degree of cartilage differentiation.

\section{Submikroskopická struktura kloubní chrupavky člověka v období 19. -38. týdne po oplození}

Byla sledována kloubní chrupavka 15 jedinců obojího pohlaví stáři 19. - 38. týdnů po oplození v transmisním elektronovém mikroskopu a 19 jedinců téhož stáŕí $\mathrm{v}$ rastrovacím elektronovém mikroskopu. Vzorky tkáně získané jednak při interrupcích, jednak při spontánních potratech byly zpracovány standardním zpưsobem.

$\mathrm{V}$ průběhu vývoje artikulární chrupavky lze vymezit období, ve kterých se zřetelně obrážeji změny $\mathbf{v}$ submikroskopické struktuře jednotlivých komponent i v utváření jejího povrchu. V prvním trimestru je to období 6.-11. týdne po oplození a dále období 19.-20. a 27.-37. týden po oplození. Tyto pozdější etapy byly předmětem našeho studia.

Již od 11. týdne po oplození lze v kloubní chrupavce odlišit tři vrstvy. V období 19. - 20. týdne se v cytoplasmě chondroblastů povrchové a střední vrstvy kromě jiných změn objevují intracytoplasmatická filamenta jako důležitý diferenciační znak a v období 27. týdne se na povrchu chrupavky objevují první známky tvorby chondrální membrány. $\mathrm{V}$ období 27.-36. týdne vývoje pokračují diferenciační změny chondroblastü, takže koncem tohoto období již buňky nabývají znaky chondrocytů dospělé chrupavky. $\mathrm{V}$ mezibuněčné hmotě dochází ke zmnožení vláknité komponenty, takže odlišeni pericelulární a intercelulární matrix zejména ve střední a hluboké vrstvě je zcela zřetelné.

Do období 19.-20. týdne vývoje je povrch chrupavky velmi nerovný. Četné chondroblasty kryté povrchovou vrstvou mezibuněčné hmoty prominuji do kloubní dutiny. V období od 27. a zvláště v období 37. týdne dochází ke snížení počtu chondroblastů, které před narozením vytvářejí charakteristické skupiny po dvou buňkách. Buňky jsou uloženy v prohlubních oddělených zářezem od okolí. Prohlubně i zářezy jsou podmíněny kolapsem vytvořené pericelulární matrix, vyvýšeniny mají jako podklad níže uložené chondroblasty.

\section{Сүбмикроскопическая стрүктүра сүставного хряща человека на 19 - 38 неделе после оплодотворения}

Проводили исследования суставного хряща 15 особей обоего пола в возрасте 19 - 38 недель после оплодотворения с помощью трансмиссионной микроскопии и 19 особей в том же возрасте в раствором 
электронном микроскопе. Образцы ткани, полученные во время абортов и самопроизвольных абортов обрабатывали обычным способом.

В ходе развития артикулярного хряща можно определить период, В котором четко на петедний план выступают изменения субмикроскопической структуы отдельных компонентов и формирования его поверхности. В первом триместре речь идет о периоде 6 - 11 недель после оплодотворения и о периоде 19-20 и 27-37 недель после оплодотворения. Приведенные более поздние периоды легли в основу наших исследований.

Уже с 11 недели после оплодотворения можно в суставном хряще различить три слоя. На $19-20$ неделе в цитоплазме хондробластов поверхностного и среднего слоев помимо других изменений появляются интрацитоплазметические филаментарные волокна в качестве важного дифференцирующего признака и на 27 неделе на поверхности хряща появляются первые признаки образования хондральной мембраны. На 26 - 36 неделе развития продолжается дифференциация хондробластов, следовательно, в конце указанного периода клетки уже приобретают характер хондроцитов взрослого хряща. В межклеточной массе увеличивается количество волокнистой составляющей, следовательно, совершено четко выделяется различие перицеллюлярного и интерцеллюлярного слоев в особенности в среднем и глубоком уровнях.

На 19-20 неделе развития поверхность хряща неровная. Многочисленные хондробласты, покрытые поверхностным слоем межклеточной массы выходят в суставную полость. Начиная с 27, в особенности на 37 неделе численность хондробластов уменьшается и данные хондробласты перед рождением образуют характерные группы парных клеток. Углубления и выемы обусловлены коллапсом образуемого перицеллюлярного слоя, выстүпы имеют в качестве основы ниже расположенные хондробласты.

\section{References}

AGRAWAL, P.-ATRE, P. - KULKARNI, D. S.: The role of cartilage canals in the ossification of the talus. Acta Anat., 119, 1984: 238-241

ALI, S. Y.: Analysis of matrix vesicles and their role in the calcification of epiphysal cartilage. Fed. Proc., 35, 1976: 136-142

ANDERSON, H. G. - SAJDERA, S. W.: Calcification of rachitic cartilage to study matrix vesicle function. Fed. Proc., 35, 1976: 148-152

BLOEBAUM, R. D. - WILSON, A. S.: The morphology of the surface of articular cartilage in adult rats. J. Anat. (London), 131, 1980: 333-346

BONUCCI, E.-DEARDEN, L. C.: Matrix vesicles in ageing cartilage. Fed. Proc., 35, 1976: $163-168$

CLARKE, I. C.: Surface characteristic of human articular cartilage -a scanning electron microscope study. J. Anat. (London), 108, 1971 a: 23-30

CLARKE, I. C.: Human articular surface countours and related surface depression frequency studies. Ann. rheum. Dis., 30, 1971 b: $15-23$

CLARKE, I. C.: Articular cartilage: a review and scanning electron microscope study. II. The territorial fibrillar architecture. L. Anat. (London), 118, 1974: 261-280

CURTISS, P. H.-KLEIN, L.: Destruction of articular cartilage in septic arthritis. II. In vivo studies. J. Bone Jt. Surg., 47 A, 1965: 1595-1614

CIHÁK, R.: Ontogenesis of the skeleton and intrinsic muscles of the human hand and foot. Erg. Anat. Entwickl. Gesch., 46, 1972: 1-25

DEARDEN, L. C.-BONUCCI, E.-CUICCHIO, M.: An investigation of ageing in human costal cartilage. Cell Tissue Res., 152, 1974: 305-337 
DRACHMAN, D. B.-SOKOLOFF, L.: The role of movement in embryonic joint development. Develop. Biol., 14, 1966: 401-420

FELIX, R. - FLEISCH, H.: Role of matrix vesicles in calcification. Fed. Proc., 35, 1976: 169-171

FREEMAN, M. A. R.-MEACHIM, G.: Ageing degeneration and remodelling of articular cartilage. In: Adult articular cartilage. Ed. M. A. R. Freeman. Alden Press, Oxford, 1973

GARDNER, E.-O'RAHILLY, R.: The early development of the knee joint in staged human embryos. J. Anat. (London), 102, 1968: 289-299

GARDNER, E.-GRAY, D. J.: The prenatal development of the human femur. Am. J. Anat., 129, 1970: $121-140$

CHADIALLY, F. N.-MEHTA, P. N.-KIRKALDY-WILLIS, W. H.: Ultrastructure of articular cartilage in experimentally produced lipoarthrosis. J. Bone Jt Surg., 52 A, 1970: 1147 to 1158

GHADIALLY, F. N.-MOSHURCHAK, E. M. - GHADIALLY, J. A.: A maturation change in the surface of cat articular cartilage detected by the scanning electron microscope. J. Anat. (London), 125, 1978: 349-360

GHADIALLY, F. N. - YONG, N. K. - LALONDE, J.-M. A.: A transmission electron microscopic comparison of the articular surface of cartilage processed attached to bone and detached from bone. J. Anat. (London), 135, 1982: 685-706

GHADIALLY, F. N.: Fine structure of synovial joints. Butterworths, London 1983

GLENISTER, T. W.: An embryological view of cartilage. J. Anat. (London), 122, 1976: 323-330

GODMAN, G. C.-LANE, N.-PORTER, K. R.: Chondrogenesis. Studies with the electron microscope. J. Biophys. Biochem. Cytol., 8, 1960: 719-732

GOLDBERG, B.-GREEN, H.: An analysis of collagen secretion by established mouse fibroblast lines. J. Cell Biol., 22, 1964, 227-258

GOULD, R. P. - SELWOOD, L.-DAY, A.: The mechanism of cellular orientation during early cartilage formation in the chick limb and regenerating amphibian limb. Exp. Cell Res., 83, 1974: $287-296$

GRAY, D. J.-GARDNER, E.: Prenatal development of the human humerus. Am. J. Anat., 124, 1969: $431-446$

GRAY, J.-GARDNER, E.-O'RAHILLY, R.: The prenatal development of the skeleton and joints of the human hand. Am. J. Anat., 101, 1957: 169-223

HAINES, R. W.: Cartilage canals. J. Anat. (London), 68, 1933: 45-64

HANAOKA, H.: The fate of hypertrophic chondrocytes of the epiphyseal plate. An electron microscopic study. J. Bone Jt Surg., 58, 1976: 226-229

HORKŸ, D.: Submicroscopic structure of the human joint cartilage. Acta Vet. Brno, 49, 1980: $145-176$

HORKY, D.: Ontogenic development of the ultrastructure of bovine joint cartilage. Acta vet. Brno, 52, 1983: 103-130

HORKÝ, D.: Ultrastruktura kloubní chrupavky a synoviální membrány skotu v ontogeneze. Acta Facult. Med. Univ. Brunensis, 57, 1984: 319

HORKY, D.: Ultrastructure of bovine articular cartilage between weeks 8 and 23 of prenatal development. Acta vet. Brno, 55, 1986: 227-246

HORKÝ, D.: Submicroscopic structure of bovine articular cartilage in prenatal and early postnatal period. Acta vet. Brno, 56, 1987: 3-18

HURREL, D. J.: The vascularization of cartilage. J. Anat. (London), 69, 1934: 47-61

LAZARIDES, E.: Intermediate filaments as mechanical integrators of cellules space. Nature (London), 283, 1980: 249-256

LEVENE, C.: The pattern of cartilage canals. J. Anat. (London), 98, 1964: 515-538

LEVITT, D. - DORFMAN, A.: Concept and mechanism of cartilage differentiation. In: Current Topics in Developmental Biology. Ed: Moscona and Monroy, Academic Press, New York, London, 1974

LONGMORE, R. B. - GARDNER, D. L.: Development with age of human articular cartilage surface structure. Ann rheum. Dis., 34, 1975: 26-37.

LONGMORE, R. B. - GARDNER, D. L.: The surface structure of ageing human articular cartilage: A study by reflected light interference microscopy. J. Anat. (London), 126, 1978: 353-365

LUFTI, A. M.: The mode of growth, fate and function of cartilage canals. J. Anat. (London), 106, 1970: $135-145$

MAROUDAS, A.-EVANS, H.-ALMEIDA, L.: Cartilage of the hip joint. Ann. rheum. Dis., 32, 1973: 1-9

McCONAILL, M. A.: The movements of bones and joints. The mechanical structure of articulating cartilage. J. Bone Jt Surg., 33 B, 1951: 251-257

MCCUTCHEN, C. W.: Boundary lubrication by synovial fluid: demonstration and possible osmotic explanation. Fed. Proc., 25, 1966: 1061 
MEACHIM, G. - STOCKWELL, R. A.: Adult articular cartilage. Ed: M. A. R. Freeman, Alden Press, Oxford, 1973

MEACHIM, G.-FERGIE, I. A.: Morphological patterns of articular cartilage fibrillation. J. Pathol, 115, 1975: $231-240$

MEACHIM, G.-STOCKWELL, R. A.: The matrix, In: Adult articular cartilage, 2nd edition. Ed: M. A. R. Freeman, Pitman Medical, London, 1979

MOSHURCHAK, E. M.-GHADIALLY, F. N.: A maturation change detected in the semilunar cartilages with the scanning electron microscope. J. Anat. (London), 126, 1978: 605-618.

O'RAHILLY, R. - GARDNER, E.: The timing and sequence of events in the development of the limbs in the human embryo. Anat. Embrýol., 148, 1975: 1-23

PALFREY, A. J.-DAVIES, D. V.: The fine structure of chondrocytes. Am. J. Anat., 100, 1966: $213-228$

PORTER, K. R. - TUCKER, J. B.: The ground substance of the living cell. Sci Ann., 244, 1981 : 56-67

PƯSCHMANN, H.: Scanning and transmission electron microscopic studies of the development of the joint surfaces. Anat. Anz., 143, 1978: 399-406

REVEL, J. P.-HAY, E. D.: An autoradiographic and electron microscopic study of collagen synthesis in differentiating cartilage. Z. Zellforsch., 61, 1963: 110-144.

ROBERTS, K. - HYAMS, J. S.: Microtubules. Academic Press, New York, London, 1979.

SHELLDON, H. - KIMBALL, F. B.: Studies on cartilage. III. The occurence of collagen within vacuoles of the Golgi apparatus. J. Cell Biol., 12, 1962: 559-613

SCHERFT, J. P.: The lamina limitans of the organic matrix of calcified cartilage and bone. J. Ultrastruct. Res., 38, 1972: 318-331

SCHERFT, J. P.-DAEMS, W. Th.: Single cilia in chondrocytes. J. Ultrastruct. Res., 19, 1967: $546-555$

STINGL, J.: Ultrastruktura synoviálních struktur $\mathrm{v}$ časné ontogeneze člověka. Sborník prací III. kongr. o sportovní traumatologii, Třeboň, 1982

STOCKWELL, R. A.: The cell density of human articular and costal cartilage. J. Anat. (London), 101, 1967: 753-763

STOCKWELL, R. A.: The ultrastructure of cartilage canals and the surrounding cartilage in the sheep fetus. J. Anat. (London), 109, 1971: 397-410

STOCKWELL, R. A.-MEACHIM, G.: Adult articular cartilage. Ed: M. A. R. Freeman, Alden Press, Oxford, 1973

STOCKWELL, R. A.-MEACHIM, G.: The chondrocytes. In: Adult articular cartilage. 2nd edition. Ed: M. A. R. Freeman, London, Pitman Medical 1979

VIDINOV, N.-VASILEV, V.: Cilia in rat articular chondrocytes. Anat. Anz, Jena, 158, 1985: $51-55$

VIGNON, E.-ARLOT, M.-PATRICOT, L.M.-VIGNON, G.: The cell density of human femoral head cartilage. Clin. Orthop., 121, 1976:303-308

WEISS, C.-ROSENBERG, L.-HELFET, A. J.: An ultrastructural study of normal young adult human articular cartilage. J. Bone Jt Surg., 50 A, 1968: 663-674

WEISS, C.-MIRROW, S.: An ultrastructural study of osteoarthritic changes in the articular cartilage of human knees. J. Bone Jt Surg., 54 A, 1972: 954-972

WILTBERGER, H.-LUST, G.: Ultrastructure of canine articular cartilage: comparison of normal and degenerative (osteoarthritic) hip joints. Am. J. Vet. Res., 36, 1975: 727-740

WOLF, J.: Chondrosynoviální blanka a její význam. Sborník lékařský, Praha, 48, 1946: 277-286

WOLF, J.: Chondrosynovial membrane serving as joint cavity lining with a sliding and barrier function. Folia morphol. (Prague), 17, 1969: 291-308

WOLF, J.: Function of chondral membrane of surface of articular cartilage from point of view of its mechanical resistence. Folia morphol. (Prague), 23, 1975: 77-87

ZIMNY, M. L.-REDLER, I.: Scanning electron microscopy of chondrocytes. Acta Anat. (Basel), 83, 1972: 398-402 
Plate IX.

Horký D.: Submicroscopic Structure of Human Articular Cartilage ... pp. 111-126.




Plate IX.

Fig. 1 Surface layer of human articular cartilage, 19 to 20 weeks after fertilization. Chondroblasts with nuclei $(\mathrm{N})$, karyosomes $(\mathrm{k})$. Short profiles of granular endoplasmic reticulum in cytoplasm (E), mitochondria with damaged cristae (M), Golgi complex (G), lysosomes (L), glycogen ( $\mathrm{g}$ ), cytoplasmic filaments only in the vicinity of the nucleus (f) or cell membrane, the exception being support structures (d) between projections of cells (c). Some of the projections are located immediately under the surface. Intercellular substance already contains collagenous fibrils $(\mathrm{K})$ radiating in various directions in the amorphous ground substance (za). Magnification: $12000 \times$. 
Plate X.

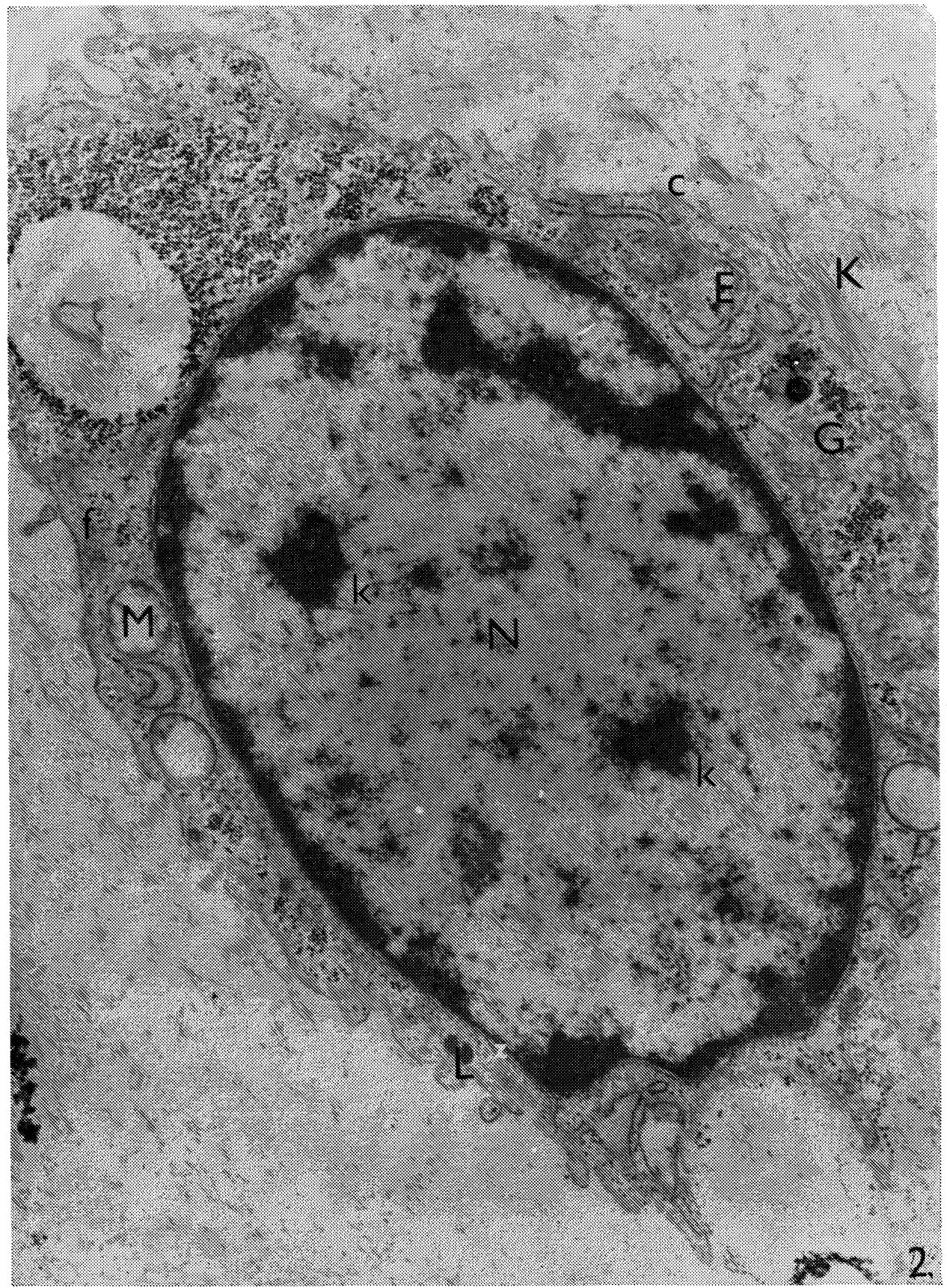


Plate X.

Fig. 2 Chondroblasts of the middle layer of human articular cartilage, 19 to 20 weeks after fertilization. Nucleus $(\mathrm{N})$, karyosomes $(\mathrm{k})$, zonula nucleum limitans ( $\mathrm{z}$ ), sporadic profiles of granular endoplasmic reticulum (E), structures of Golgi complex (G), mitochondria with damaged cristae (M), lysosomes (L), glycogen (g), cytoplasmic filaments (f), collagenous fibrils $(\mathrm{K})$ are frequently placed near cellular membrane (c).

Magnification: $16000 \times$ 
Plate XI.

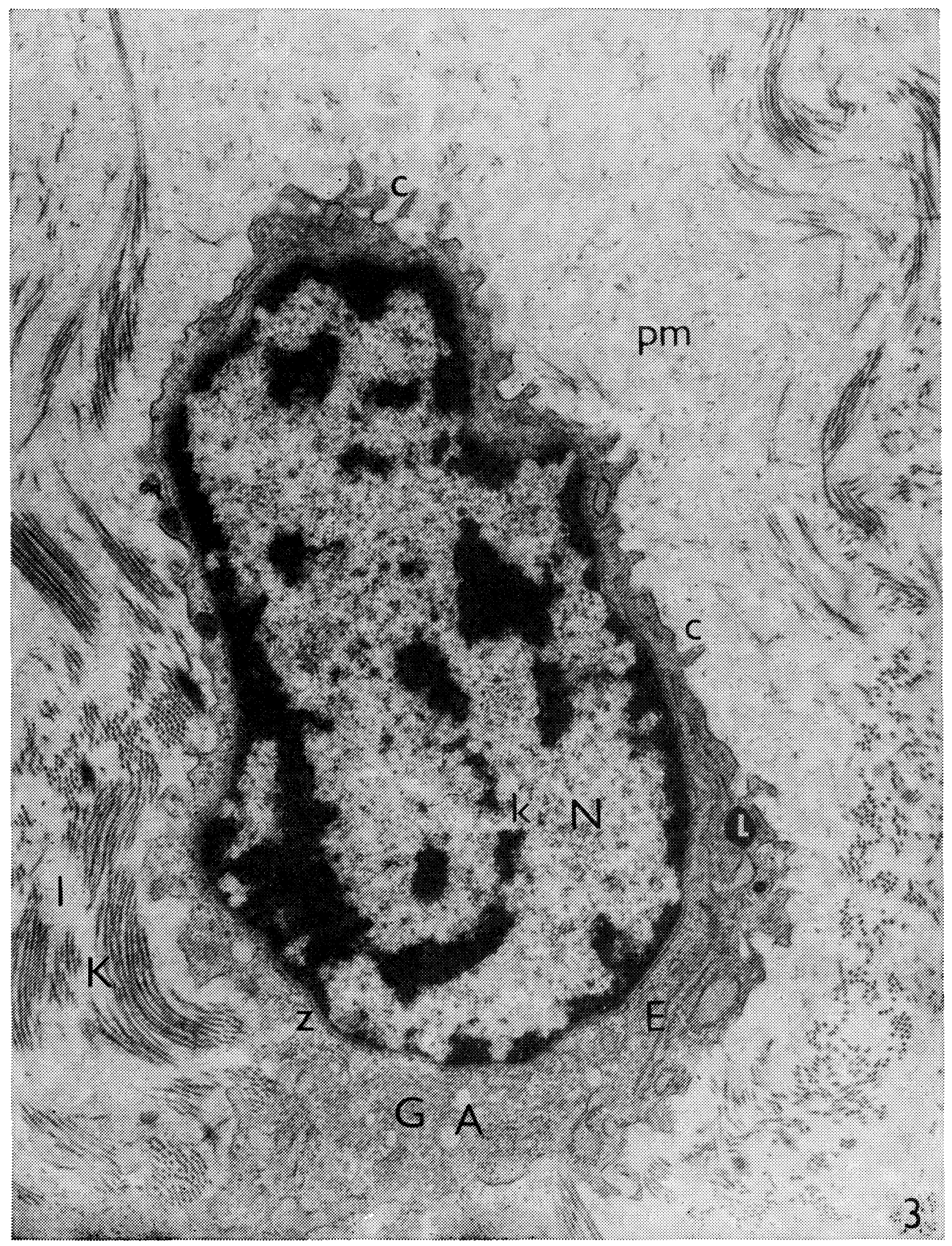


Plate XI.

Fig. 3 A chondroblast of the deep layer of human articular cartilage, 19-20 weeks after fertilization. Nucleus (N) with karyosomes (k), zonula nucleum limitans (z), cisternae and vesicles of granular endoplasmic reticulum (E), agranular endoplasmic reticulum (A), small vesicles of Golgi complex (G), lysosomes (L). Numerous short processes of cytoplasm (c) penetrating into the perinuclear matrix $(\mathrm{pm})$ or intercellular matrix $(\mathrm{I})$ where a part of collagenous fibrils $(\mathrm{K})$ is arranged parallel to the surface of the cell. Magnification: $16000 \times$. 
Plate XII.

Plate XII.

Fig. 4 Part of intercellular substance of the deep layer of human articular cartilage, $19-20$ weeks after fertilization. Bundles of collagenous fibrils $(\mathrm{K})$ and clusters of fine fibrous material $(\mathrm{fm})$, collagenous fibrils are divided from its amorphous ground substance (za). Magnification: $28000 \times$.

Fig. 6 Part of the surface layer of human articular cartilage, 27 to 37 weeks after fertilization. Nucleus of the chondroblast $(\mathrm{N})$, cisternae of granular endoplasmic reticulum (E), mitochondria (M), cytoplasmic filaments (f). Bundles of fibrous material in intercellular substance are set either under the surface or deeper under the chondroblast. Magnification: $12000 \times$. 


\section{Plate XIII.}

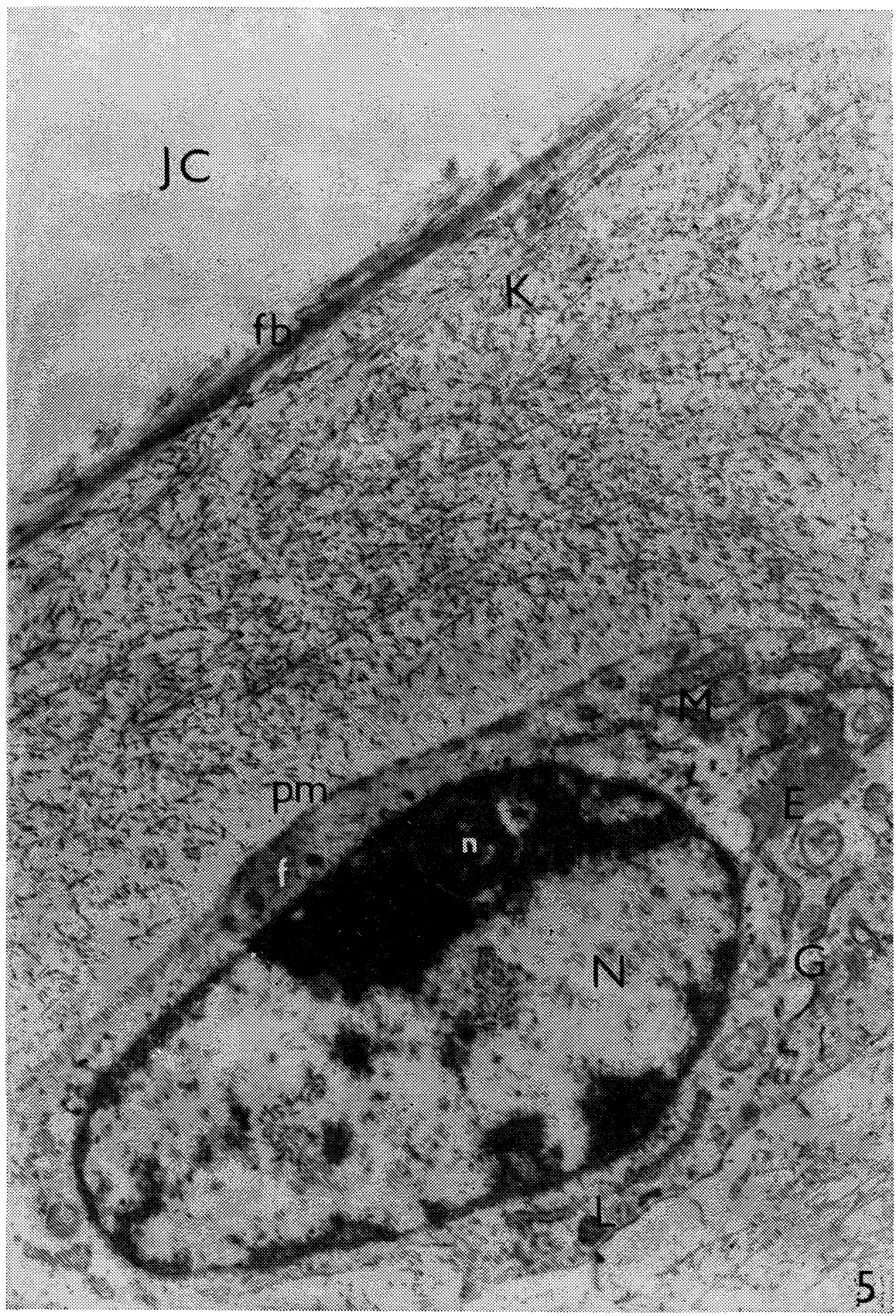


Plate XIII.

Fig. 5 Part of surface layer of human articular cartilage, 27 to 37 weeks after fertilization. Nucleus of chondroblasts $(\mathrm{N})$, nucleolus of the reticular type (n). Narrow cisternae and dilated vesicles of granular endoplasmic reticulum (E) with granular material, small Golgi complex (G), mitochondria (M), lysosomes (L). Intracytoplasmic filaments (f) set perinuclearly. Pericellular matrix $(\mathrm{pm})$, collagenous fibrils $(\mathrm{K})$ in intercellular matrix. Fine filaments in bundles $(\mathrm{fb})$ on the surface of the cartilage and individual fibrils going into the joint cavity (JC). Magnification: $16100 \times$. 
Plate XIV.
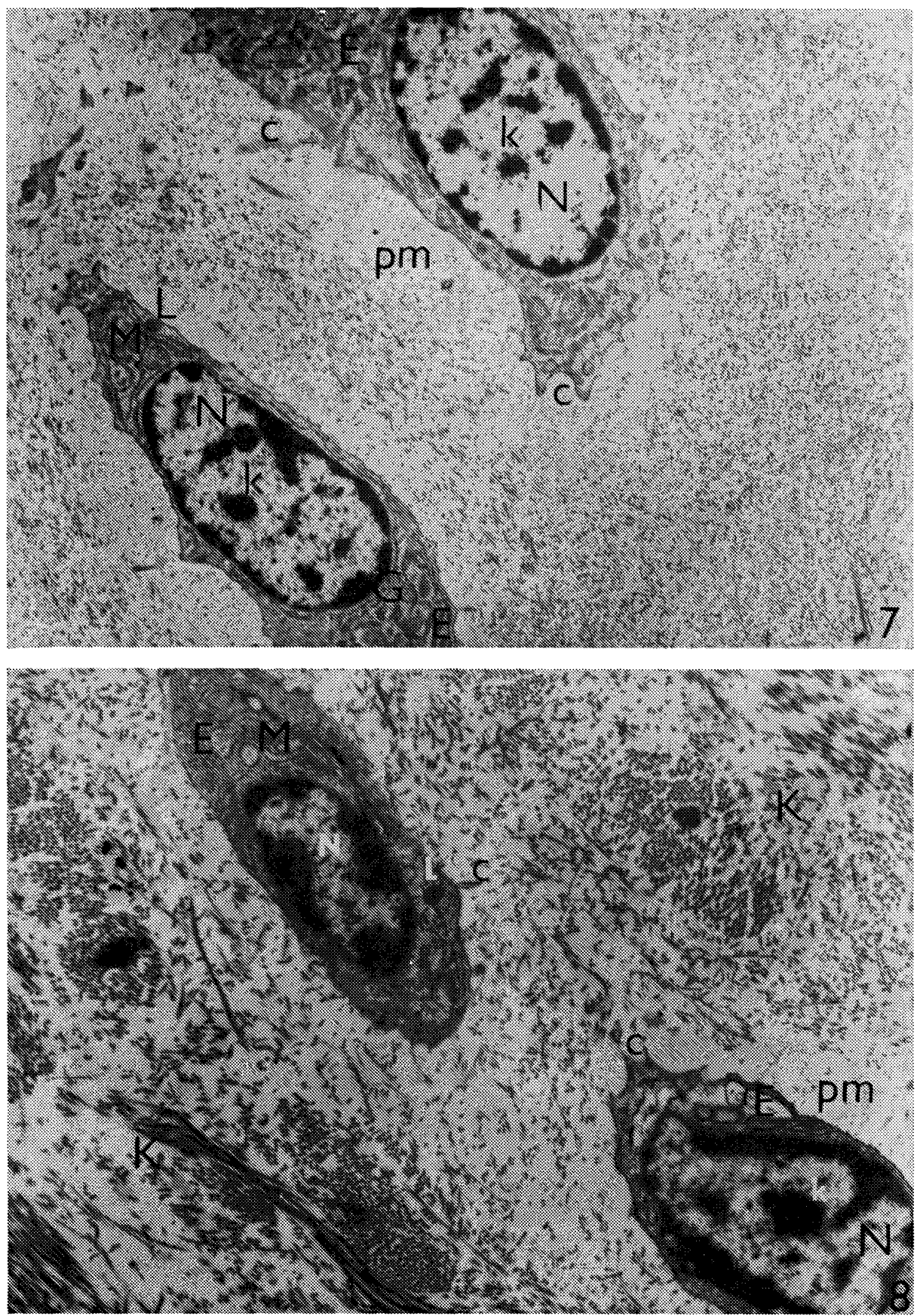


\section{Plate XIV.}

Fig. 7 Pair of chondroblasts of the middle layer of human articular cartilage, 27 to 37 weeks after fertilization. Nucleus (N), karyosomes (k). Numerous narrow cisternae of granular endoplasmic reticulum (E), vesicles of Golgi complex (G), mitochondria $(M)$, lysosomes (L). Sporadic processes of cytoplasm (c) projecting into pericellular matrix (pm). Numerous collagenous fibrills in intercellular substance, forming partitions between lacunae. Magnification: $12000 \times$.

Fig. 8 Part of deep layer of human articular cartilage, 27 to 37 weeks after fertilization. Nucleus of chondroblasts $(\mathrm{N})$, karyosomes (k). Both narrow and dilated cisternae of granular endoplasmic reticulum (E), small mitochondria (M), lysosomes (L). Short processes of cytoplasm (c) do not exceed the region of pericellular matrix (pm), if formed. Numerous bundles of collagenous fibrils $(\mathrm{K})$ radiating in various directions in intercellular matrix. Magnification: $12000 \times$. 





Plate XV.

Fig. 9 Part of the surface of human articular cartilage, 19 to 20 weeks after fertilization. Group of four prominent chondroblasts $(\mathrm{V})$ set in folded intercellular substance. Cellular detritus (d) on the surface. Scanning electron microscopy. Magnification: $6000 \times$.

Fig. 10 Part of the surface of human articular cartilage, 36 weeks after fertilization. Prominences (V) are low and the surface between them slightly irregular. Remains of synovial fluid (d). Magnification: $6000 \times$. 


\section{Plate XVI.}
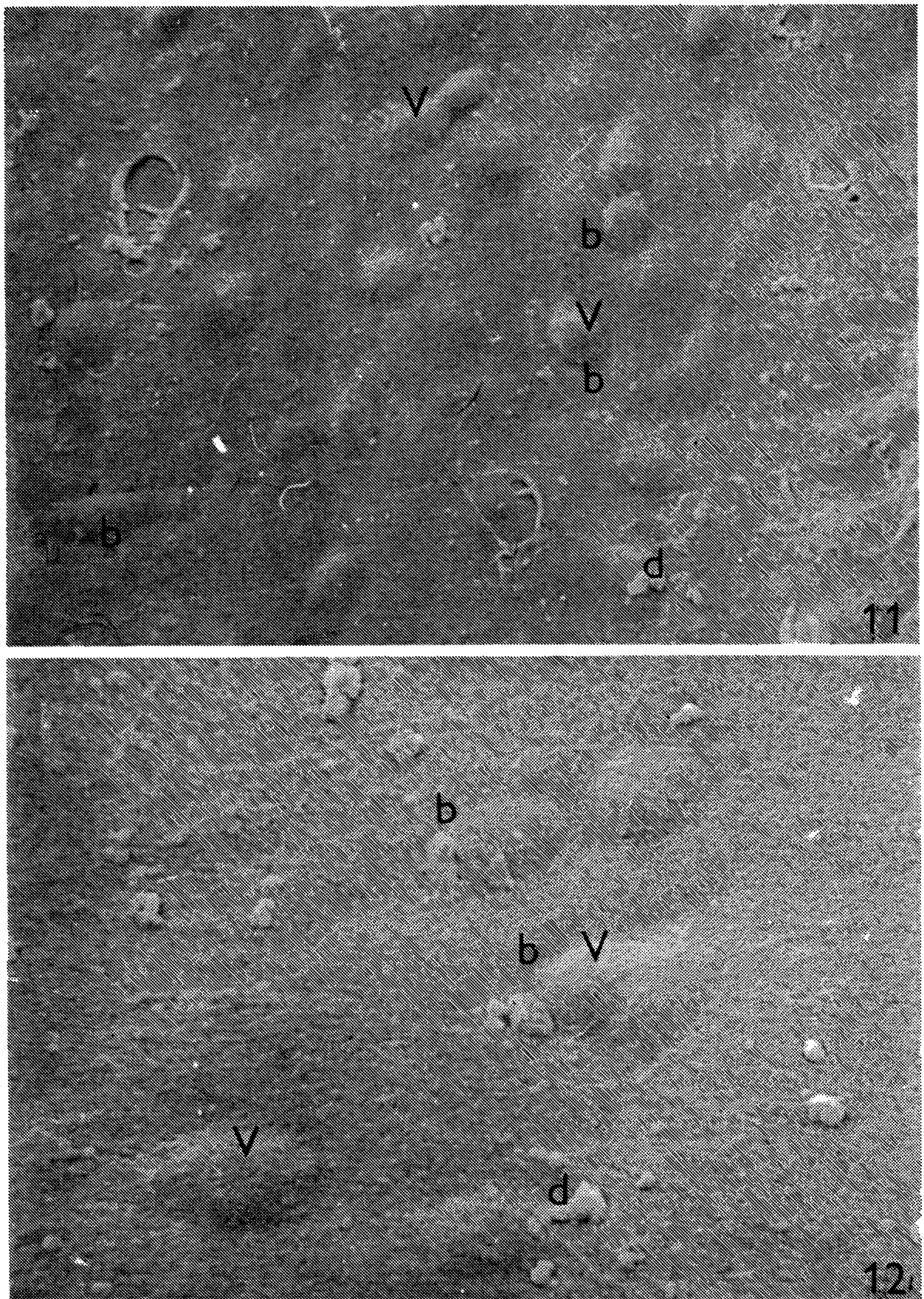
Plate XVI.

Fig. 11 Part of the surface of human articular cartilage, 38 weeks after fertilization. Both individual and paired prominences $(V)$ are separated from the surrounding area by a shallow groove (b). The surface between prominences is covered with small irregularities. Cellular detritus (d). Scanning electron microscopy. Magnification: $2000 \times$.

Fig. 12 Detailed view of human articular cartilage, 38 weeks after fertilization. Prominences on the surface (V) are bordered by a shallow groove (b), separating them from the surrounding surface covered with tiny projections or ridges. Cellular detritus (d). Scanning electron microscopy. Magnification: $4000 \times$. 